syn på kristendommen, hvorefter tilværelsens virkelighed kun kan fremstilles som et mytisk drama, hvis indhold er grundtvigsk: overgangen fra mørke og død til lys og liv. Vigtigst er den tyske teolog Bonhoeffer, der var kritisk over for Bultmanns afmytologisering af evangeliet. I hans teologi er metaforen »midte afgørende. Kristendommen skal ikke kun møde mennesket i grænsesituationer, men skal ses som nærværende centrum (midt) i eksistensen og historien. Bonhoeffers teologi skal have mindelser om Grundtvigs syn på de to testamenters frelseshistoriske sammenhæng og på ordets nærvær i gudstjenesten.

Som det ses, vil Schjørring ved at pege på Grundtvigs mytiske kristendomssyn åbne for en anden teologi end det 20. årh.s rationalisme og kriticisme, især Bultmanns. Han giver indrømmelser, holder spørgsmål åbne, men tendensen er klar. Nok skal teologien medtænke moderne erkendelse, men »dens genstand er den samme som gudstjenestens« (173), og den er ikke sideordnet med liturgien, men kommer bagefter som kritisk eftertanke. Det oprindelige er gudstjenesten, og i den kan traditionen blive nærværende ved og i et "helbibelsk « billedsprog som Grundtvigs.

Jens Holger Schjørrings bog er konstruktiv og mangesidig, men alligevel giver den appetit på endnu mere. For i hans gennemgang af Grundtvigs billedsprog savnes et stort og vigtigt område, nemlig væksttanken og antropologien eller vækst-antropologien, som findes spredt rundt om i salmerne, også i bogens hovedstykke »I Kveld blev der banket«. Den er en uopløselig del af salmerne, og den knytter sig til trosbekendelsen og er formet over de mange treklange hos Grundtvig. Området er dog så omfattende, at det her og nu må blive ved denne antydning. Men Schjørrings igangsættende bog lægger op til en fortsættelse, der går ud over teologiens grænser.

\title{
Grundtvigs bibelhistoriske sange
}

\section{Af Henning Høirup}

Bibelhistoriske sange om den gamle og den nye pagt, samlet og udgivet ved Jørgen Glenthøj. Forlaget BHS (Borum Byvej, Borum, 8471 Sabro). 1990. 480 sider. 150 $k r$.

Denne sangbog genoptager på smukkeste måde den tradition med at udsende Grundtvigs bibelhistoriske sange i særskilt udgave, som blev grundlagt i 1832, hvor stud. theol. L.C. Hagen samlede og udgav Historiske Psalmer og Riim til Børne-Lardom, bestående af »lutter grundtvigske Omarbejdelser og ny Sange «. Af de 68 numre blev de 9 her for første gang trykt (se Steen Johansen: Bibliografi over N.F.S. Grundtvigs Skrifter I, s. 284). Om tilblivelsen af denne »Hagens Salmebog «, som den blev kaldt, beretter Chr. S. Ley livfuldt i en samtidig optegnelse: „Hagen har ret glæde af at komme til Gr. i denne tid. Han siger, hvilke salmer han vil have forandrede. Så sætter Gr. sig hen i hjørnet af sofaen og digter, og Hagen skriver op. Mens Hagen er borte, så gør Gr. også ny salmer eller ændrer på de gamle«. 
Hagens skønsomme udvalg af det store, spredte materiale og hans igangsættende samarbejde med Grundtvig er mindeværdigt i dansk salmehistorie. Hans samling kom i flere oplag, det sjette og sidste i 1856 øget med 24 numre. Men da havde allerede en anden samling, som efterhånden fortrængte Hagens, set lyset: Bibelske og Kirkehistoriske Psalmer og Sange for Skolen, som Grundtvigs svigersøn, pastor P.O. Boisen udgav i 1853 . Grundtvig gav ham »velvilligen sit Minde til at samle og udgive af hans trykte og utrykte Psalme-Arbeider, og til de Forandringer og Forkortelser, som maatte ansees tjenlige for Skolen«. Som forsanger i „Danske Samfund «, som stiftedes i 1839 efter Grundtvigs »Mands Minde «-foredrag, og som Grundtvigs håndgangne hjælper ved udgivelse af dennes folkelige og kristelige digtninge til sangbrug var Boisen særdeles velskikket til opgaven. Hans sangbog vandt hurtigt vid udbredelse og kom, inden århundredets udgang, i 10 udgaver. Efter 11. udgave (Gyldendal 1912) gik den helt af brug. Siden blev kun en del af dens sange, de mest benyttede, optrykt i andre sangbøger, frem for alt i Folkehøjskolens Sangbog, ofte i kortere form. Ingen dristede sig til at foretage en samlet udgivelse $i$ lighed med Boisens.

$\mathrm{Nu}$ fremlægger sognepræst, lic. theol. Jørgen Glenthøj, et veritabelt genoplivningsfors $\emptyset \mathrm{g}$ af hele denne sangskat, som delvis er gået i glemme, ja han har tilmed udvidet den. Boisen bringer 112 numre af Grundtvig. Glenthøj ikke mindre end 180 af bogens ialt 208 numre. Det højere antal skyldes dels at Glenthøj medtager flere sange end Boisen, dels at han opdeler mange lange digte i flere sange.

Nyvalgte er f. eks. de to indledende sange, nr. 0 om Bibelen: »Tag Bogen af den engels hånd«, der tjener som samlingens »øsen« og bringes $\mathrm{i}$ sin helhed (efter Grundtvigs Sang-Værk II, 1946, Tillæg s. V), og nr. 1 om Ordet: „O, hvor har det hjemme - et ypperligt udvalg på 9 strofer af GSV II no. 1: »Skabelsen«. Nr. 192 »Petrus, Paulus og Johannes« er ligeledes' nytilkommet $(9$ strofer udvalgt af originalens 16 , GSV II no. 95).

Den anstødssten, som de lange Grundtvig-tekster frembyder, har Glenthøj i flere tilfælde søgt at fjerne - ikke ved som sine forgængere at forkorte, men ved at opdele $\mathrm{i}$ en sekvens af sange. Som eksempel på denne redaktionsteknik kan nævnes digtet om Syndfloden (GSV II no. 8), hvor Boisen som nr. 6 bringer 32 af originalens 54 strofer i een sang, medens Glenthøj medtager dem alle, delt $i$ fem sange, nr. 12-16. Af sangen om Guldkalven (GSV II no. 31) udtager Boisen som nr. 2317 af de 27 strofer, begyndende med den syvende. Glenthøj medtager hele digtet, delt i tre sange, nr. 60-62. Af Grundtvigs maraton-epos, bygget over Sirachs Lovsang kap. 44-50: „Kom, lad os prise de herlige Mænd “ (GSV II no. 56) benyttede Boisen strofe 19-20 og 25-67, fordelt på seks sange, som Glenthøj overtager uændret. Tillige bringer han de resterende strofer, udstykket i fire sange, således at hele digtet foreligger klar til brug i nr. 112-121.

I Boisens nr. 86 ændres begyndelseslinien i Grundtvigs digt Opstandelsen (Dansk Kirketidende 1845-56, sp. 505-10): „Velkommen, store Fødselsdag " til "Hilsæl, du store fødselsdag«, og originalens 45 strofer nedskæres til 35. Glenthøj derimod følger redaktionen i GSV II no. 41, der indfører den ny begyndelse: „Luk øjne op, al kristenhed « og forkorter til 41 strofer, som fordeles på fem sange, nr. 184-188. 
Glenthøj foretrækker således, med få og små undtagelser, at gengive Grundtvigs sange $\mathrm{i}$ deres helhed. En sådan uforkortet udgivelse af de sprogligt righoldige tekster går, som Glenthøj skriver, unægtelig imod strømmen i nutiden, med dens bestræbelser for at nedskære ordforrådet til det mest mulig dagligdags, men wimødekommer samtidig en nyvakt hunger efter en højnelse og udvidelse af det danske folks ordforråd «.

Med Boisens udgaver som forbillede, men med direkte brug først og femmest af udgaven af Grundtvigs Sang-Værk I-VI, 1944-56, har Glenthøj søgt at skabe en sangbog for alt, hvad der kan komme ind under begrebet »kirke-skolen«. Det er hans håb, at den kan komme i brug ikke blot i skoler og ved konfirmandforberedelsen, men også ved menighedsmøder, i studiekredse og i hjemmene, hvor "den sungne bibelhistorie « kan virke til fornyelse og til fordybelse $i$ de bibelske tekster, som ligger til grund og som overalt er anført under sangene.

Det må hilses med glæde, at Glenthøjs udgave af »Bibelhistoriske Sange« nu, efter et prisværdigt grundigt og principfast redaktionsarbejde, foreligger som et vellykket og værdigt sidestykke til sin nærmeste forgængers fortjenstfulde arbejde - »i mere nutidig skikkelse « hedder det i forordet. Dette betyder slet ikke, at Glenthøj - som den igangværende nyoversættelse af Bibelen - søger at forenkle og reducere sprogdragten til skrabet "Nudansk «, f. eks. ved totalt at udrydde kerneord som "miskundhed « og "velbehag «, der siden reformationen har levet $i$ vor Gudstjeneste. Der er intetsteds foretaget slige »moderniseringer « af hævdvundne bibelske grundord; men i stedet bringes en liste med ordforklaringer, der gør det nemt at tyde gammeldags begreber. Ved »nutidig skikkelse « forstås blot, at der anvendes nugældende retskrivning og at Grundtvigs mange bindestreger og spatieringer udelades. Selve tekstgengivelsen er overalt tro.

Fldre læsere, der i århundredets begyndelse blev fortrolige med Boisens sangbog, vil i Glenthøjs genfinde dens sange, ikke sjældent endda i udvidet form - f. eks. har to af de mest kendte: nr. 41 »Jeg havde min vugge ved Nilens bred« fået originalens første strofe med, og nr. 3 »Gud planted en have fra øst til vest« er øget fra 11 til 17.

Sangene er forsynet med melodier, både de ældre af Lindeman og Hartmann, de nyere af især Th. Aagaard, Th. Laub og Oluf Ring, og derudover som resultat af en komponistkonkurrence eller efter opfordring til kendte kirkekomponister - med 24 helt nye melodier til sange, som ikke tidligere har været tonesat eller som skønnedes at trænge til ny melodi. Samtlige melodier udgives i en melodibog i flerstemmig udsættelse.

Det store arbejde, som Glenthøj under medvirken af en konsulentgruppe har udført både med tekster og melodier, er sket ud fra den rigtige erkendelse, at vi i Grundtvigs bibelhistoriske digtning ejer et alt for lidt benyttet hjælpemiddel til tilegnelse af »den kristelige børnelærdom«. 